\title{
ШЛЯХИ ОПТИМІЗАЦІЇ ФАНГОКОРЕКЦІЇ СТАНУ ЗДОРОВ'Я ВІЙСЬКОВОСЛУЖБОВЦІВ: РЕКОМЕНДАЦІЇ ЛІКАРЮ-РЕАБІЛІТОЛОГУ
}

\author{
О.П. Шматенко ${ }^{1}$, О.Ф. Кучмістова ${ }^{1}$, І.В. Бушуєва ${ }^{2}$, \\ В.0. Тарасенко ${ }^{1}$, В.О. Кучмістов ${ }^{1}$, А.М. Кричковська ${ }^{3}$
}

\author{
1 Українська військово-медична академія (м. Київ) \\ 2 Запорізький державний медичний університет (м. Запоріжжя) \\ 3 Національний університет «Львівська політехніка» (м. Львів)
}

Вступ. Успішне вирішення завдань, покладених на медичну службу вимагає високого рівня забезпеченості особового складу вітчизняних Збройних Сил максимально широким спектром лікувальнопрофілактичних засобів, у т.ч. природного походження. Украйна займає позицію лідера серед європейських країн за рівнем забезпеченості цінними природними лікувальними ресурсами, за їх значимістю одними з найбагатших вважаються південно-східні регіони - Дніпропетровський та Запорізький, що й обумовило об'єкт дослідження. Як показав скринінг-аналіз, до сьогодні залишаються повністю не з'ясованими особливості формування ресурсного потенціалу цих регіонів, не узагальнені потужні можливості проведення лікувально-реабілітаційної роботи засобами природного походження серед військовослужбовців на відповідних курортних і позакурортних територіях.

Мета дослідження - розширити можливості оптимізації застосування рекреаційних можливостей південно-східних регіонів України в місцях можливої дислокації військовослужбовців.

Матеріали та методи. Застосовували загально-наукові та системно-оглядові методи інформаційного пошуку, зокрема скринінг-аналіз, систематизація та інтерпретація їі результатів, маркетингових досліджень.

Результати. Вперше здійснена порівняльна кількісно-якісна оцінка найпотужніших бальнеогрязьових джерел як ланки природного рекреаційно-ресурсного потенціалу Дніпропетровщини та Запоріжчини. Прослідковано взаємозв'язок виявлених ресурсів пелоїдів із напрямками проведення стаціонарного лікування у реабілітаційному відділенні санаторно-курортних закладів на території обраних регіонів. Фрагментарно висвітлено результати маркетингового дослідження бальнеогрязьових препаратів як сегментів фармацевтичного ринку. Відмічена його насиченість за країнами-виробниками, асортиментом, можливими лікарськими формами. Означені чіткі переваги пелоїдопрепаратів у порівнянні з розчинами нативної грязі, властивості яких майже тотожні. Вичленено найбільш цікаві позиції для можливого розширення спектру проведення відновлювального лікування військовослужбовців, особливо на місцях відповідної дислокації, що є цілком зрозумілим і доречним.

Висновки. Порівняльна оцінка відповідних ресурсів обраних регіонів виявила схожість типу мінералізації грязей (сульфідно-мулові) та відповідного спектру надання лікувально-реабілітаційних послуг в умовах санаторно-курортних закладів, розташованих на цих територіях. Вичленено водогрязелікарні та інші заклади, що спещіалізуються на обслуговуванні учасників ОоС. Означено, що протягом особливого періоду вони повинні перетворитися у військові госпіталі та використовуватися за призначенням. Проаналізовано численні випадки успішної реабілітації наслідків воєнних травм, поранень різної етіології, переломів, хірургічних втручань, тяжких тривалих захворювань після курсу застосування нативних грязей або пелоїдопрепаратів. Наведені приклади не вичерпують лікувальний потенціал пелоїдів у якості замісної терапії, що визначає актуальність розробки нових лікарських засобів на їх основі. Узагальнені сучасні підходи до проведення пелоїдотехніки. Вважаємо раціональним продовжити дослідження означеного напрямку, що дозволить розширити межі реалізації оздоровчо-рекреаційного ресурсу кожного регіону України. Це дозволить максимально скоротити підгострий період реабілітації та повернути військовослужбовия до строю. Викладений матеріал доводить, що грязелікування має залишатися невід'ємною часткою реабілітаційної програми для особового складу вітчизняних Збройних Сил, особливо в сучасних історичних умовах.

Ключові слова: військовослужбовці, лікувальні грязі, пелоїди, пелоїдопрепарати, реабілітація, Дніпропетровська та Запорізька області.

Вступ. Військово-медична служба $є$ важливою складовою Збройних Сил (3С) України, яка здійснює постійне піклування про збереження та зміцнення здоров'я особового складу військ. На сучасному складному історичному етапі вельми актуальним - 3 точки зору продовження проведення Операції об'єднаних сил (ООС) - $\epsilon$ мобілізація усіх можливих засобів для забезпечення високої боєздатності 
військовослужбовців. Успішне вирішення завдань, покладених на медичну службу, вимагає високого рівня забезпеченості особового складу вітчизняних 3С максимально широким спектром лікувальнопрофілактичних засобів, у т.ч. природного походження. 3'ясувалось, що Україна займає позиції лідера серед європейських країн за рівнем забезпеченості цінними природними лікувальними ресурсами [1,3], за географічним положенням знаходиться у виключно сприятливих умовах [6], причому за значимістю природних ресурсів одними 3 найбагатших вважаються південно-східні регіони - Дніпропетровська та Запорізька обл., що й обумовило об'єкт проведеного дослідження. У XIX ст. територіально це були складові єдиної Катеринославської губернії (Бекетов, 1886; Акінфієв, 1889; Сидоров, 1897), тому більшість дослідників проводили фізико-географічні та біолого-екологічні дослідження цих регіонів як єдиного цілого, що зумовлено історично $[11,21]$. Як показав скринінг-аналіз, до сьогодні залишаються повністю не з'ясованими особливості формування ресурсного потенціалу Дніпропетровщини і Запоріжчини, не узагальнені потужні можливості проведення лікувально-реабілітаційної роботи засобами природного походження серед військовослужбовців на відповідних курортних і позакурортних територіях.

Мета дослідження. Представити науково-практичний підхід до оптимізації застосування рекреаційних можливостей південно-східних регіонів України в місцях можливої дислокації військовослужбовців на підставі: а) систематизації інформації щодо кількісно-якісних характеристик лікувальних грязей (ЛГ) Дніпропетровської та Запорізької обл. як складової гідромінеральних ресурсів, структуризації лікувального профілю санаторно-курортних закладів на означених територіях; б) вичленення найбільш цікавих позицій в ході маркетингового огляду сучасних бальнеогрязьових лікарських засобів (ЛЗ) для розширення спектру надання лікувально-реабілітаційних послуг.

Матеріали та методи. Об’єктами дослідження були екологічні паспорти означених регіонів України, дисертаційні дослідження, наукові статті, довідкові Internet-сайти за обраною тематикою. У ході дослідження застосовували загально-наукові та системно-оглядові методи інформаційного пошуку: скринінг-аналіз, систематизація та інтерпретація iㅣ результатів, методи маркетингових досліджень тощо. Представлено фрагмент проведеного дослідження природно-рекреаційного потенціалу окремих регіонів України у якості замісної терапії для особового складу військових частин у мирний період i на основних (потенційних) театрах воєнних дій.

Результати дослідження та їх обговорення. Природні ресурси - екологічна, господарська, наукова, оздоровча цінність кожної держави. Цікавим $\epsilon$ дослідження Парфіненка А.Ю. та ін. (2018), в якому наголошується схожість природних умов і наявних лікувальних ресурсів України до європейських. Насамперед, це Польща, Словаччина, Угорщина та Чехія - світові лідери на ринку курортів (spa), лікувальнооздоровчого туризму [14]. Наша країна відноситься до провідних мінеральносировинних країн Європи, в надрах якої (на території $0,4 \%$ земної суші) сконцентровано 5\% мінерально-сировинного потенціалу світу $[13,18]$. Його подальше вивчення та використання для охорони здоров'я військовослужбовців, за думкою провідних фахівців, є раціональним $[1,4,11,20,22]$. Насамперед, це стосується реабілітаційного періоду (терміни проведення, об'єм допомоги) iз застосуванням природного рекреаційно-ресурсного потенціалу (ПРРП) країни, за рахунок чого можливо суттєво полегшити стан хворого/пораненого, прискорити одужання (після перенесеної бойової травми, операційного втручання, на етапі доліковування після тяжких виснажливих захворювань) та повернути військовослужбовця до виконання своїх професійних обов'язків.

На I-му етапі дослідження було узагальнено історичні та нормативно-правові аспекти застосування ЛГ, основні характеристики означеного лікувальнооздоровчого природного (рекреаційного) фактору на прикладі Дніпропетровської та Запорізької обл. України (у порівняльному аспекті), структуровано напрямки проведення санаторно-курортного лікування в оздоровчих закладах цих регіонів. Авторами проаналізовано основні вимоги чинного 
законодавства країни щодо використання природних ресурсів, нормативно-правові основи їх обліку, використання та охорони [6, 10, 15-17, 19].

Виходячи 3 літературних даних, теоретичною основою для лікувальнооздоровчого застосування природних факторів стала санаторно-курортна справа, зародження якої відбулося в епоху Стародавнього Світу (IV ст. до н.е. - V ст.) [5, 9]. Перші відомості щодо спроб організації відновлення боєздатності поранених і хворих у межах діючої армії відносять до сер. XVIII ст. Проф. Пирогов M.I. включив грязелікування до реабілітаційної програми для поранених під час Кримської війни, що дало змогу значно скоротити терміни відновлення й поліпшити результати лікування [1]. Власне з відкриттям i використанням ЛГ (therapeutic muds) або пелоїдів історично розпочався розвиток курортів, а згодом і рекреаційних ресурсів окремих регіонів [9, 12]. Передумовою про наявність експлуатаційних запасів, наприклад, на Азовському узбережжі (сучасний район курорту Кирилівка Запорізької обл.) послужили результати робіт, проведені ще наприкінці XIX ст. [2].

Упродовж тривалого часу ПРРП України використовували понад 800 санаторно-курортних закладів, у яких щорічно проходило лікування понад 1 млн людей [16]. Означені заклади, зокрема що знаходяться у підпорядкуванні Міністерства оборони України, вважаються військовими частинами, на які покладено мобілізаційні завдання. На особливий період вони повинні перетворитися у військові госпіталі та використовуватися за призначенням [1].

Проведений скринінг-аналіз виявив думку провідних фахівців, які вважають означений лікувально-оздоровчий чинник природного середовища найпотужнішим. ЛГ - це природні органо-мінеральні колоїдальні утворення, що мають високу теплоємність та теплоутримувальну здатність, містять терапевтично активні речовини (солі, гази, біостимулятори тощо) та живі мікроорганізми. До головних характеристик пелоїдів належать: загальний виражений терапевтичний вплив завдяки їх фізичним властивостям, органічному й мінеральному складові, вмісту біологічно активних сполук БАР (оксиди заліза, мідь, алюміній, кобальт, амінокислоти, вуглеводень, сірководень, азот, a також гормоно-, антибіотико- i вітаміноподібні речовин) $[8,22]$. Присутність мікроорганізмів - обов'язкова умова пелоїдогенезу, вони сприяють структуруванню, збагачують БАР метаболізму і підтримують визначені кислотні й окиснювально-відновні умови. Кількість мікроорганізмів може досягати понад 1 млрд у 1,0 сухого пелоїду [5]. Компоненти грязей визначають їх бактеріостатичні та бактерицидні властивості, специфічною ознакою є здатність до регенерації.

Загалом станом на 01.01.2019 р. в Україні розвідано і затверджено близько 200 родовищ ЛГ (балансові запаси понад 1,7 млн $\mathrm{M}^{3}$ ), обсяг відповідного рекреаційного потенціалу країни становить 25 млн людинодоз. Вітчизняні пелоїди представлені практично усіма відомими генетичними типами [6]. Авторами узагальнено та структуровано картографічно-довідковий матеріал, лікувально-оздоровчі властивості пелоїдів.

Щодо Запорізької Ta Дніпропетровської обл., вони не лише географічно суміжні, займають приблизно однакову територію, мають сприятливі грунтово-кліматичні умови та потужні запаси мінеральної сировини. За різноманітністю та значимістю природних ресурсів вважаються одними 3 найбагатших в Україні, оцінюються фахівцями як ресурсозбалансований та відносно ресурсозбалансований відповідно [6]. Виявлена тотожність складу ЛГ цих регіонів (переважно сульфідно-мулові), здатність ефективно впливати як на місцевий запальний процес, так й на всі основні органи та системи. Найбільш активними по всій Україні вважаються пелоїди Запоріжжя [8]. Авторами узагальнені сучасні підходи до фанголікування (інші можливі назви: пело-, пелоїдо-, грязелікування), сучасні технології його проведення. Результати цього етапу дослідження частково представлено у вигляді таблиць: загальна кількісно-якісна оцінка ресурсів ЛГ на території Дніпропетровщини та Запоріжчини у порівняльному аспекті (табл. 1) та більш детальна характеристика найпотужніших бальнеогрязьових джерел кожного з цих регіонів (табл. 2). 
Таблиця 1.

Порівняльна оцінка ресурсів лікувальної грязі, напрямків та форм проведення пелоїдолікування за регіонами України, що досліджувалися

\begin{tabular}{|c|c|c|}
\hline \multirow[t]{2}{*}{ Показники } & \multicolumn{2}{|c|}{ Адміністративні області } \\
\hline & Дніпропетровська & Запорізька \\
\hline Балансові запаси, тис м³ & 24700 & 250600 \\
\hline Видобуток за рік, тис м ${ }^{3}$ & 0,202 & 0,324 \\
\hline Тип мінералізації & \multicolumn{2}{|c|}{ переважно сульфідно-мулові } \\
\hline $\begin{array}{l}\text { Приклади найбільш потуж- } \\
\text { них родовищ регіону }\end{array}$ & $\begin{array}{l}\text { Солонолиманське родо- } \\
\text { вище (Новомосковський р- } \\
\text { н, с. Новотроїцьке) }\end{array}$ & $\begin{array}{l}\text { родовища «Озеро } \text { Велике» } \\
\text { (Бердянська коса), «Обітич- } \\
\text { не», «Кирилівське» }\end{array}$ \\
\hline $\begin{array}{c}\text { Порівняльна } \\
\text { нцінка псті пелоїдів }\end{array}$ & середня активність & $\begin{array}{l}\text { найбільша активність по всій } \\
\text { Україні, аналог відомих куро- } \\
\text { ртів Саки і Карлові Вари }\end{array}$ \\
\hline $\begin{array}{l}\text { Частка санаторно-курортних } \\
\text { закладів на території регіону } \\
\text { у загальному об'ємі оздоров- } \\
\text { чих закладів країни }\end{array}$ & $7,1 \%$ & $6,4 \%$ \\
\hline $\begin{array}{l}\text { Наявність санаторно-курорт- } \\
\text { них закладів, які забезпечу- } \\
\text { ють учасників оОС, осіб } 3 \\
\text { інвалідністю }\end{array}$ & $\begin{array}{l}\text { •санаторій «Славутич» } \\
\text { (м. Верхньодніпровськ) } \\
\text { •санаторій «Сонячний» } \\
\text { (Павлоградський р-н) }\end{array}$ & $\begin{array}{l}\text { - санаторій «Бердянськ» } \\
\text { (м. Бердянськ) } \\
\text { - санаторій «Нива» } \\
\text { (м. Бердянськ) }\end{array}$ \\
\hline $\begin{array}{l}\text { Галузі застосування } \\
\text { пелоїдотерапії }\end{array}$ & \multicolumn{2}{|c|}{$\begin{array}{l}\text { Загальна дія: благотворний вплив на стан опорно-рухового } \\
\text { апарату та внутрішніх органів, післяопераційні стани, зміна } \\
\text { імунологічної реактивності організму (зниження алергічних } \\
\text { проявів); виражена заспокійлива, тонізуюча, антиоксидан- } \\
\text { тна дія; підвищення імунного статусу, синдром хронічної } \\
\text { втоми. } \\
\text { Місцева дія (в зоні ураження): ефекти протизапальний, } \\
\text { болетамувальний, розсмоктуючий (спайки, рубці, зрощен- } \\
\text { ня); покращення трофіки тканин. } \\
\text { Високоефективною є реабілітація після поранень, переломів, } \\
\text { опіків, травм. }\end{array}$} \\
\hline \multirow[t]{2}{*}{ Форми пелоїдолікування } & \multicolumn{2}{|c|}{$\begin{array}{l}\text { Традиційні методики: грязьові ванни (загальні, місцеві), } \\
\text { аплікації, компреси (загальні, місцеві), інгаляції, мікро- } \\
\text { клізми, бовтанки, ін'єкції (підшкірні, внутрішньом'язові), } \\
\text { суспензії, огортання (фанготерапія), тампони, компреси, } \\
\text { зрошення, полоскання, ПП (екстракти, гумізолі, віджими, } \\
\text { мазі тощо) }\end{array}$} \\
\hline & \multicolumn{2}{|c|}{$\begin{array}{l}\text { Нові методики (кріопелоїдотерапія, грязьові стоматоло- } \\
\text { гічні аплікації, метод тонкошарової термоконтрастної } \\
\text { грязьової аплікації з попереднім нагріванням шкіри тощо) }\end{array}$} \\
\hline Реалізованість ПРРП & & \\
\hline
\end{tabular}

На підставі наведених даних цілком зрозумілі напрямки проведення санаторнокурортного лікування. На території обох регіонів вичленено водогрязелікарні та інші санаторно-курортні заклади, які спеціалізуються на обслуговуванні учасників ООС (наслідки бойової травми, у т.ч. стани після поранень, опіків, переломів; перенесеного операційного втручання, тяжких виснажливих захворювань різної етіології). Наведені дані дають чітке уявлення про високу рекреаційну потужність обох регіонів, що досліджувалися. Наприклад, запаси мулових ЛГ Дніпропетровщини дозволяють проводити оздоровлення в сумарній кількості 18,3 тис чол. Враховуючи, що пелоїди підлягають 
регенерації (3-4 міс.), до розрахунку порогової ємності приймається $65 \%$ від визначеної величини - 11,9 тис чол. [6].

Як показано у табл. 2, у більшості випадків показанням до проведення пелоїдотерапії $€$ захворювання органів руху (для підвищення рухливості суглобів, забезпечення швидкого та тривалого полегшення при больовому синдромі), периферійної нервової системи, дерматологічні, жіночої статевої сфери та органів дихання. Також ЛГ ідеально підходять для реабілітації після медичних втручань, наслідків бойової травми, тривалих тяжких захворювань.

Цілком зрозуміло, що кожному регіонові притаманна власна природно- рекреаційна система (кліматичні та мікрокліматичні умови, ландшафт, флористичний склад, типи грунтів, бальнеологічні та бальнеогрязьові родовища тощо), що суттєво впливає на лікувально-оздоровчий напрямок відповідних закладів. На підставі аналізу літературних джерел, авторами вичленено найбільш затребувані лікувальні процедури (грязьові ванни та аплікації). Надається рекомендація з обережністю застосовувати гарячі грязьові аплікації хворим, які знаходяться на медикаментозному забезпеченні. Адже при поєднанні пелоїдотерапії із прийомом лікарських чи інших засобів, здатних викликати місцеву гіперемію, $\epsilon$ небезпека виникнення дерматологічних проблем [8].

Таблиця 2.

\section{Характеристика найпотужніших бальнеогрязьових джерел окремих південно-} східних регіонів України

\begin{tabular}{|c|c|c|}
\hline $\begin{array}{c}\text { Географічне } \\
\text { розташування }\end{array}$ & $\begin{array}{c}\text { Хімічний склад солей } \\
\text { розчину пелоїдів }\end{array}$ & Лікувально-профілактичні властивості \\
\hline \multicolumn{3}{|c|}{ Дніпропетровська область } \\
\hline $\begin{array}{l}\text { м. Верхньо- } \\
\text { дніпровськ } \\
\text { (санаторій } \\
\text { «Славутич»)* }\end{array}$ & $\begin{array}{l}\text { Сульфідно-мулові } \\
\text { грязі; вміст іонів } \\
\text { хлору, брому }\end{array}$ & $\begin{array}{l}\text { Показання до застосування: захворювання } \\
\text { (гіпертонічна } \\
\text { стенокардія напруги; органів травлення, опорно-рухової, } \\
\text { сечостатевої, нервової системи, ЛоР-органів, урологічні } \\
\text { хвороби. }\end{array}$ \\
\hline $\begin{array}{l}\text { Дніпро- } \\
\text { дзержинський } \\
\text { р-н } \\
\text { с. Романково } \\
\text { (санаторій } \\
\text { «Дніпровський»)* }\end{array}$ & $\begin{array}{l}\text { Органічні сполуки } \\
\text { солі, кислоти, мі- } \\
\text { нерали, мікроеле- } \\
\text { менти }\end{array}$ & $\begin{array}{l}\text { Показання: захворювання органів дихання неспецифічного } \\
\text { характеру, жіночої статевої системи, патологї̈ вагітності, } \\
\text { систем кровообігу (гіпертонія, кардіосклероз, міокардіт, } \\
\text { вроджені вади серця), нервової системи (неврози, стреси, } \\
\text { наслідки запалень ЦнС, розлади сну); реабілітаційне } \\
\text { лікування опорно-рухового апарату та шкіри після опіків. }\end{array}$ \\
\hline $\begin{array}{l}\text { Павлоградський } \\
\text { р-н } \\
\text { с. Вербки } \\
\text { (санаторій } \\
\text { «Сонячний»)* }\end{array}$ & $\begin{array}{l}\text { Пелоїди унікаль- } \\
\text { ного складу Сло- } \\
\text { в'янського } \quad \text { родо- } \\
\text { вища; вміст сірко- } \\
\text { водню, йодобром-на } \\
\text { вода }\end{array}$ & $\begin{array}{l}\text { Пелоїди Сакського озера (для внутрішньо порожнинного } \\
\text { застосування) і озера Солений лиман (зовнішньо), усі види } \\
\text { бальнеотерапії. Показання: захворювання опорно-рухового } \\
\text { апарату, системи кровообігу, нервової, ССС, органів } \\
\text { дихання, післяопікові хвороби шкіри - грязьові аплікації, } \\
\text { гальваногрязь, грязьові розвідні ванни; ванни сірко- } \\
\text { водневі, скипидарні, морські, йодо-бромні, із хвоєю та } \\
\text { шавлією. }\end{array}$ \\
\hline $\begin{array}{l}\text { Новомосковський } \\
\text { р-н } \\
\text { с. Новотроїцьке } \\
\text { (фізіотерапевтична } \\
\text { лікарня } \\
\text { «Солений Лиман») }\end{array}$ & $\begin{array}{l}\text { Мулові грязі хло } \\
\text { ридносульфатно- } \\
\text { гідрокарбонатно- } \\
\text { натрієвого складу }\end{array}$ & 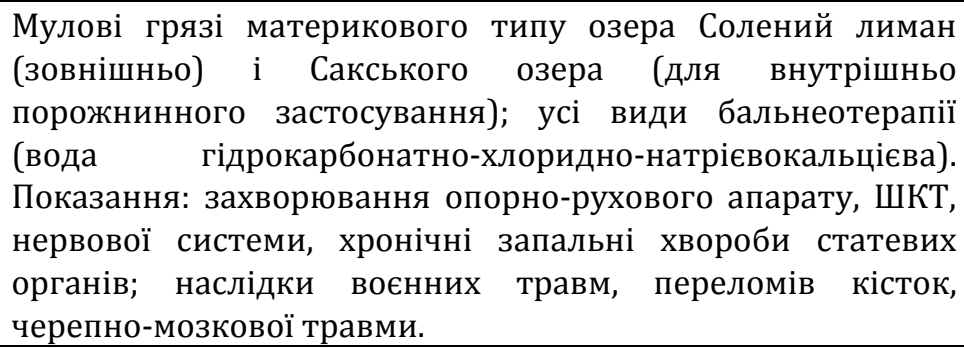 \\
\hline $\begin{array}{c}\text { Новомосковський } \\
\text { р-н } \\
\text { с. Орловщина } \\
\text { (санаторій } \\
\text { «Орловщина») }\end{array}$ & $\begin{array}{l}\text { Сульфідно-мулові } \\
\text { грязі; вміст іонів } \\
\text { хлору, натрію, йоду, } \\
\text { брому }\end{array}$ & $\begin{array}{l}\text { Показання: зміцнення імунітету, синдром хронічної втоми; } \\
\text { захворювання опорно-рухового апарату, органів } \\
\text { травлення, ССС, нервової, ендокринної систем; патологій } \\
\text { обміну речовин; } \quad \text { післяопераційні } \\
\text { загальнотонізуючий ефект. }\end{array}$ \\
\hline
\end{tabular}


Продовження таблиці 2.

\section{Характеристика найпотужніших бальнеогрязьових джерел окремих південно-} східних регіонів України

\begin{tabular}{|c|c|c|}
\hline $\begin{array}{c}\text { Географічне } \\
\text { розташування }\end{array}$ & $\begin{array}{c}\text { Хімічний склад солей } \\
\text { розчину пелоїдів }\end{array}$ & Лікувально-профілактичні властивості \\
\hline \multicolumn{3}{|c|}{ Запорізька область } \\
\hline $\begin{array}{c}\text { м. Бердянськ } \\
(\text { (санаторій «Нива»)* }\end{array}$ & \begin{tabular}{|l}
\multicolumn{2}{l}{ Сульфідно-мулові } \\
грязі; вміст іонів \\
хлору, натрію, бро- \\
му
\end{tabular} & $\begin{array}{l}\text { Грязьові озера в Бердянську. Показання: захворювання } \\
\text { ШКТ, урологічні, ЛОР-органів, опорно-рухового апарату } \\
\text { (артрити, артрози); порушення ССС, сечостатевої, } \\
\text { ендокринної, нервової систем (хронічні радикуліт); } \\
\text { покращення обміну речовин, патологія вагітних, наслідки } \\
\text { опікової хвороби. }\end{array}$ \\
\hline $\begin{array}{l}\text { м. Бердянськ } \\
\text { (санаторій } \\
\text { «Бердянськ»)* }\end{array}$ & $\begin{array}{l}\text { Сульфідно-мулові } \\
\text { грязі; вміст іонів } \\
\text { хлору, брому, йоду }\end{array}$ & $\begin{array}{l}\text { Грязьові озера в Бердянську. Показання: захворювання } \\
\text { ССС, ендокринної, ЦНС і периферичної нервової систем, } \\
\text { опорно-рухового апарату, верхній дихальних шляхів, } \\
\text { шкіри, органів травлення; гінекологічні, урологічні та } \\
\text { стоматологічні проблеми; порушення обміну речовин. }\end{array}$ \\
\hline $\begin{array}{l}\text { м. Запоріжжя } \\
\text { (санаторій } \\
\text { «Великий Луг»)* }\end{array}$ & $\begin{array}{l}\text { Сульфідно-мулові } \\
\text { грязі; вміст іонів } \\
\text { хлору, брому, йоду }\end{array}$ & $\begin{array}{l}\text { Показання: захворювання ССС, нервової систем, опорно- } \\
\text { рухового апарату, органів травлення (печінки та } \\
\text { жовчовивідних шляхів), органів зору, патологія вагітних - } \\
\text { ванни (сухі вуглекислі, кисневі, перлинні, морські, } 3 \\
\text { шавлією та хвоєю), грязьові аплікації, гальваногрязь. }\end{array}$ \\
\hline $\begin{array}{c}\text { м. Бердянськ } \\
\text { (санаторій } \\
\text { «Нафтохімік } \\
\text { України» }\end{array}$ & $\begin{array}{l}\text { Сульфідно-мулові } \\
\text { грязі; вміст іонів } \\
\text { брому, йоду }\end{array}$ & $\begin{array}{l}\text { Грязьові озера в Бердянську. Показання: захворювання } \\
\text { опорно-рухового апарату; ССС, ендокринної, сечостатевої, } \\
\text { нервової систем; ШКТ, органів дихання. }\end{array}$ \\
\hline $\begin{array}{c}\text { Якимівський р-н } \\
\text { с. Кирилівка } \\
\text { (санаторій } \\
\text { «Кирилівка»)* }\end{array}$ & $\begin{array}{l}\text { Сульфідно-мулові } \\
\text { грязі; вміст іонів } \\
\text { хлору, натрію }\end{array}$ & $\begin{array}{l}\text { Показання: захворювання периферичної нервової, } \\
\text { кістково-м'язевої, статевої (у жінок і чоловіків) систем; } \\
\text { органів дихання (не туберкульозного походження) та } \\
\begin{array}{l}\text { травлення - грязьові аплікації, } \\
\text { електрогрязелікування, грязерозчинні ванни. }\end{array}\end{array}$ \\
\hline $\begin{array}{l}\text { м. Бердянськ } \\
\text { (санаторій } \\
\text { «Арктика»)* }\end{array}$ & $\begin{array}{l}\text { Вміст сірководню, } \\
\text { інших газів мінера- } \\
\text { льних солей; іонів } \\
\text { хлору, йоду, брому }\end{array}$ & $\begin{array}{l}\text { Грязьові озера в Бердянську. Програми оздоровчо- } \\
\text { лікувальні: «Антистресова», «Обмін речовин», «Жіноче } \\
\text { здоров'я», «Чоловіче здоров'я», «Здорові судини», } \\
\text { «Здоровий хребет». Показання: загартовування, } \\
\text { захворювання опорно-рухового апарату, ШКТ, шкіри, } \\
\text { хронічні захворювання легень, проблеми з кроворухом, } \\
\text { неврози, стреси, хвороби органів тазу, депресії. }\end{array}$ \\
\hline $\begin{array}{l}\text { м. Бердянськ } \\
\text { (санаторій } \\
\text { «Лазурний»)* }\end{array}$ & $\begin{array}{l}\text { Сульфідно-мулові } \\
\text { грязі; вміст іонів, } \\
\text { хлору, брому, йоду }\end{array}$ & $\begin{array}{l}\text { Грязьові озера в Бердянську. Показання: захворювання } \\
\text { органів кровообігу, дихання (не туберкульозного } \\
\text { походження), периферичної нервової системи; кістково- } \\
\text { м'язової, ендокринної, сечостатевої системи (у жінок і } \\
\text { чоловіків), органів травлення. }\end{array}$ \\
\hline
\end{tabular}

Безумовно, максимально ефективним $\epsilon$ проведення курсів пелоїдолікування в санаторно-курортних закладах, на території/поблизу яких є власні родовища ЛГ (наприклад, грязьові озера в Бердянську). За відсутністю такої можливості, суттєво скоротити терміни проведення лікувальнореабілітаційної роботи дозволяє застосування пелоїдопрепаратів (ПП), арсенал яких постійно поповнюється.
Ha II-мy emani проведено маркетингові дослідження бальнеогрязьових препаратів як сегментів фармацевтичного ринку України. За думкою провідних фахівців, препарати активованої ЛГ за своїми фізико-хімічними властивостями майже тотожні грязьовому розчину нативної грязі. Окреслені чіткі переваги ПП: високий ранозагоюючий ефект при механічних i опікових ураженнях, антибактеріальний (по відношенню до патогенної/умовно-патогенної мікрофлори), 
імуномодуляторний, забезпечення специфічної політерапії, біологічна активність, антиалергенність; зручність для транспортування, зберігання та застосування $[12,22]$. У санаторіях-профілакторіях країн СНД ці засоби широко використовуються в методиках електро- i фонофорезу [22]. Загалом та території цих країн функціонує близько 100 грязелікувальних курортів, де основним лікувальним фактором $\epsilon$ грязі. Іноді пелоїди використовують як допоміжні лікувальні фактори (Єсентуки, Любін Великий, Трускавець) [5]. Сьогодні номенклатуру вітчизняного ринку грязьові ЛФ забезпечують понад 130 іноземних фармацевтичних фірм-виробників із 40 країн світу. Серед них найбільша кількість представлена ЛЗ німецького (29) та індійського (16) виробництва. Виробництвом вітчизняних ПП займаються 11 фірм і 5 фармацевтичних фабрик [7].

При проведенні маркетингового дослідження розглядались як фасовані нативні грязі, так і фармацевтичні препарати на їх основі від різних країн-виробників (Україна, Болгарія, Італія, Данія, Росія, Естонія, Ізраїль, Угорщина, Індія). Загальна кількість уніфікованих ПП - 55. Результати цього етапу дослідження фрагментарно представлені у табл. 3. Як з'ясувалось, спектр відібраних ЛФ доволі широкий: мазь, паста, розчин, розчин для ін'єкцій, порошок, гранули, екстракт, олійний розчин, бальзам, мінерально-органічний комплекс для аплікацій та обгортань.

Досить різноманітною $€$ й лінійка лікувально-косметичних засобів: ЛГ із вітамінно-мікроелементними та фітокомпозиціями (у вигляді екстракту, гелю), засоби-біогенні стимулятори на грязьовій основі (маска, мило, мило-скраб, тонік, шампунь, кондиціонер, крем тощо). Представлена продукція фасована у тубах, саше, ампулах, пакетах, пластикових крапельницях, пластмасових контейнерах, мішках, флаконах (зі скла або полімерних матеріалів). Маса фасування коливається від 0,1 до 20 кг.

Окрема увага приділялась, насамперед, нативним грязям. Найбільшим попитом у санаторіях або через торгівельну мережу користуються ЛГ або ЛГ консервовані (у тубах, саше, пластмасових контейнерах) виробництва фірм Lac Sante (Україна, м. Одеса); Sivash-Farm (Україна, м. Запоріжжя); CoolHealth (Україна, м. Дніпро); ГУНПП РК «Крымская ГГРЭС», «Кримська натуральна колекція» (АР Крим); «Кавминкурортресурсы» (Росія); Histomer, Вуоthea (Італія); Care\&Beauty Line, Ahava Natural Dead, Dr. Sea, SEA of SPA (Ізраїль). Фахівці неодноразово акцентують увагу на тому, що якісно-кількісні характеристики інгредієнтів ЛГ Чорного i Мертвого моря; Шаболатського ліману; озер Куяльник, Сакського i Тамбукан; затоки Сиваш; інших водних ресурсів $\epsilon$ не лише високоцінними, але й часто дещо схожими за лікувально-профілактичним спрямуванням i вираженістю оздоровчої дії.

За результатами скринінг-аналізу проводилась цінова сегментація нативної грязі від різних фірм-виробників; вичленені позиції 3 мінімальною, середньою та максимальною вартістю. Як видно 3 даних таблиці 4, максимально економічною виявилася Грязь «Сивашская» (50 грн/кг); низьку вартість має продукція АO «Кавминкурорт-ресурсы» (Росія) та CoolHealth (Україна, м. Дніпро): межа коливання складає 121,92-170,00 грн/кг. Найбільш вартісними означені дві знайдені позиції: пелоїди італійського виробництва (фірми Byothea, Histomer) - відповідно 835 грн/кг і 1155 грн/кг. Середній ціновий проміжок має продукція Lac Sante (Одеса, Данія-Україна); відповідна межа коливання складає 303,03 грн/кг і 360 грн/кг. Співставлення вартості вичленованих позицій дозволило визначити середню ціну на нативну грязь на світовому фармацевтичному ринку - 440,31 грн/кг.

Слід відмітити й постійне зростання частки грязьових ЛФ в асортименті на фармацевтичному ринку, що обумовлено їх перевагами та високими лікувальними характеристиками. Ця тенденція наочно представлена на рис. 1.

У розничному сегменті фармацевтичного ринку спостерігається чітка стабілізація роста й у грошовому виразі $(4,84 \%)$. Мають зміни в регіонах, що слідують за Києвом. Зокрема, Дніпропетровщина за цим показником вийшла в рейтингу на провідне II місце. Вперше за тривалий період позитивну динаміку роста демонструють південні та територіально малі западні області. 
Таблищя 3.

Приклади сучасних пелоїдопрепаратів, представлених на вітчизняному та іноземному ринку (фрагмент)

\begin{tabular}{|c|c|c|c|c|c|}
\hline $\begin{array}{c}\text { Найменування } \\
\text { препарату }\end{array}$ & $\begin{array}{l}\text { Форма } \\
\text { випуску }\end{array}$ & $\begin{array}{c}\text { Ціна, } \\
\text { грн }\end{array}$ & $\begin{array}{c}\text { Фірма- } \\
\text { виробник }\end{array}$ & $\begin{array}{c}\text { Сировина для } \\
\text { виготовлення } \\
\text { ЛЗ }\end{array}$ & Застосування \\
\hline $\begin{array}{l}\text { Грязь } \\
\text { лікувальна } \\
\text { Mineral Mud }\end{array}$ & $\begin{array}{c}\text { Паста } \\
\text { по } 500 \text { мл } \\
\text { у тубі }\end{array}$ & 85 & $\begin{array}{l}\text { CoolHealth } \\
\text { м. Дніпро } \\
\text { (Україна) }\end{array}$ & $\begin{array}{l}\text { Мінерально- } \\
\text { органічний } \\
\text { комплекс } \\
\text { лиманної грязі } \\
\text { Шаболатського } \\
\text { ліману }\end{array}$ & $\begin{array}{l}\text { Високоефективний засіб для } \\
\text { лікування захворювань } \\
\text { опорно-рухового апарату, } \\
\text { псоріазу, екземи, виразки } \\
\text { шлунку. При контрактурах } \\
\text { після опіків, травм, флегмон, } \\
\text { трофічних вираз-ках, ранах, } \\
\text { що довго не загоюються. }\end{array}$ \\
\hline $\begin{array}{l}\text { Грязь } \\
\text { лікувальна } \\
\text { консервована }\end{array}$ & $\begin{array}{c}\text { Комплект } \\
\text { одноразових } \\
\text { аплікацій } \\
\text { №10 по 0,125 } \\
\text { кг }\end{array}$ & 255 & $\begin{array}{l}\text { TOB «Lac } \\
\text { Sante» } \\
\text { м. Одеса } \\
\text { (Україна) }\end{array}$ & $\begin{array}{l}\text { Мінерально- } \\
\text { органічний } \\
\text { комплекс } \\
\text { лиманної грязі о. } \\
\text { Куяльник }\end{array}$ & $\begin{array}{l}\text { Засіб у вигляді аплікації на } \\
\text { суглоби при захворюваннях } \\
\text { опорно-рухового апарату та } \\
\text { нервової } \\
\text { дерматологічних проблеми, } \\
\text { (у т.ч. рубцях після опіків, } \\
\text { поранень, операцій). }\end{array}$ \\
\hline $\begin{array}{l}\text { Грязь } \\
\text { «Сивашська» }\end{array}$ & $\begin{array}{c}\text { Мішок } \\
\text { по } 20 \text { кг }\end{array}$ & 1000 & $\begin{array}{l}\text { Sivash- } \\
\text { Farm, } \\
\text { м. } \\
\text { Запоріжжя } \\
\text { (Україна) }\end{array}$ & $\begin{array}{l}\text { Мінерально- } \\
\text { органічний } \\
\text { комплекс } \\
\text { лиманної грязі } \\
\text { затоки Сиваш }\end{array}$ & $\begin{array}{l}\text { Біогенний стимулятор. } \\
\text { Болетамувальний засіб (болі } \\
\text { в кістках, суглобах, м'язах і } \\
\text { хребті; залиш-кові явища } \\
\text { при переломах і вивихах), } \\
\text { дермато-логічні } \\
\text { захворювання. }\end{array}$ \\
\hline $\begin{array}{l}\text { Еплан } \\
\text { від } 100 \text { ран }\end{array}$ & $\begin{array}{c}\text { Серветки } \\
\text { антисептичні } \\
\text { стерильні } \\
\text { №1 }\end{array}$ & $\begin{array}{c}99,4 \\
5\end{array}$ & $\begin{array}{c}\text { АРГО- } \\
\text { Україна, } \\
\text { м. } \\
\text { Запоріжжя } \\
\text { (Україна) }\end{array}$ & $\begin{array}{l}\text { Двошарові } \\
\text { серветки про- } \\
\text { сякнуті } \\
\text { екстрактом з му- } \\
\text { лової } \\
\text { лікувальної } \\
\text { грязі } \\
\end{array}$ & $\begin{array}{l}\text { Засіб першої допомоги } 3 \\
\text { антисептичною, рано- } \\
\text { загоюючою, антимікробною } \\
\text { дією, ефективний при опіках } \\
\text { і трофічних виразках. }\end{array}$ \\
\hline $\begin{array}{l}\text { Пелог } \\
\text { (Pelov }\end{array}$ & $\begin{array}{c}\text { Розчин } \\
\text { по } 500 \text { мл } \\
\text { у флаконах }\end{array}$ & 245 & $\begin{array}{c}\text { Аксімед } \\
\text { (Україна) }\end{array}$ & $\begin{array}{l}100 \% \\
\text { мінералізований } \\
\text { екстракт } \\
\text { очищеної } \\
\text { лікувальної } \\
\text { грязі }\end{array}$ & 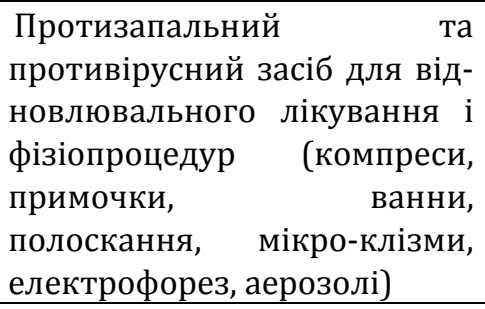 \\
\hline $\begin{array}{l}\text { ФіБC } \\
\text { (FiBC) }\end{array}$ & $\begin{array}{l}\text { Розчин для } \\
\text { ін'єкцій в } \\
\text { амп. } \\
\text { по } 1 \text { мл №10 } \\
\text { у пачках }\end{array}$ & 7,40 & $\begin{array}{c}\text { Одеське } \\
\text { ПХВО } \\
\text { (Україна) }\end{array}$ & $\begin{array}{l}\text { Препарат } \\
\text { містить відгін } \\
\text { лиманної грязі о. } \\
\text { Куяль-ник, } \\
\text { кумарин, } \\
\text { кислоту коричну }\end{array}$ & $\begin{array}{lr}\text { Засіб регуляції } & \text { процесів } \\
\text { метаболізму, } & \text { стимулює } \\
\text { обмін речовин, підвищуючи } \\
\text { резистентність } \\
\text { фізіологічні } \\
\text { організму, та } \\
\text { процеси регенерації } \\
\end{array}$ \\
\hline $\begin{array}{l}\text { Пеломарін } \\
\text { (Pelomarin) }\end{array}$ & $\begin{array}{c}\text { Крем } \\
\text { по } 70 \text { мл } \\
\text { у тубі }\end{array}$ & 95 & $\begin{array}{c}\text { Тов } \\
\text { Мануфакту } \\
\text { ра «Дім } \\
\text { природи», } \\
\text { (Україна) } \\
\end{array}$ & $\begin{array}{l}\text { Мінерально- } \\
\text { органічний } \\
\text { комплекс } \\
\text { лиманної грязі } \\
\text { Сакського озера } \\
\end{array}$ & $\begin{array}{l}\text { Біогенний } \\
\text { лікувальний засіб із вия } \\
\text { раженою ранозагоювальною } \\
\text { дією }\end{array}$ \\
\hline
\end{tabular}


Приклади сучасних пелоїдопрепаратів, представлених продовження таблиці 3. іноземному ринку (фрагмент)

\begin{tabular}{|c|c|c|c|c|c|}
\hline $\begin{array}{c}\text { Найменування } \\
\text { препарату }\end{array}$ & $\begin{array}{l}\text { Форма } \\
\text { випуску }\end{array}$ & $\begin{array}{l}\text { Ціна, } \\
\text { грн }\end{array}$ & $\begin{array}{c}\text { Фірма- } \\
\text { виробник }\end{array}$ & $\begin{array}{c}\text { Сировина для } \\
\text { виготовлення ЛЗ }\end{array}$ & Застосування \\
\hline $\begin{array}{l}\text { Пелоїдо- } \\
\text { дистилят }\end{array}$ & $\begin{array}{c}\text { Розчин } \\
\text { для } \\
\text { ін'єкцій в } \\
\text { амп. } \\
\text { по } 1 \text { мл } \\
\text { №10 }\end{array}$ & 247 & $\begin{array}{c}\text { ТОВ } \\
\text { «Біостимул } \\
\text { ятор», } \\
\text { Одеса } \\
\text { (Україна) }\end{array}$ & $\begin{array}{l}\text { Продукт відгону } \\
\text { лиман-ної грязі о. } \\
\text { Куяльник }\end{array}$ & \begin{tabular}{lrr} 
Засіб при & \multicolumn{2}{r}{ артритах, } \\
радикулітах, & міалгії, ко- \\
н'юнктивіті, & кератиті, \\
помутнінні & скловидного \\
тіла. Прискорює & процеси \\
регенерації & та & роз- \\
смоктування у патологічно \\
змінених тканинах.
\end{tabular} \\
\hline $\begin{array}{l}\text { Грязь } \\
\text { лікувальна }\end{array}$ & $\begin{array}{c}\text { Саше } \\
\text { по 0,1 кг }\end{array}$ & $\begin{array}{c}115,50 \\
*\end{array}$ & $\begin{array}{l}\text { Histomer } \\
\text { (Італія) }\end{array}$ & $\begin{array}{l}\text { Пелоїдопрепарат } \\
\text { містить ліполі- } \\
\text { тичні, дренуючі } \\
\text { та зміцнюючі } \\
\text { фактори } \\
\end{array}$ & \begin{tabular}{lr}
\multicolumn{1}{l}{ Осмотично } & активна \\
мінеральна грязь широкого \\
спектру дії, \\
$\begin{array}{lr}\text { прискорює } \\
\text { метаболізму. }\end{array}$ \\
\end{tabular} \\
\hline $\begin{array}{l}\text { Вулнузан } \\
\text { (Vulnusan) }\end{array}$ & $\begin{array}{c}\text { Мазь } \\
\text { по 45,0 } \\
\text { у тубі }\end{array}$ & 205 & $\begin{array}{c}\text { Софарма } \\
\text { (Болгарія) }\end{array}$ & $\begin{array}{l}\text { Стандартизован } \\
\text { ий розчин із } \\
\text { маткового лугу } \\
\text { Поморійського } \\
\text { соляного озера, } \\
\text { олія рицини }\end{array}$ & 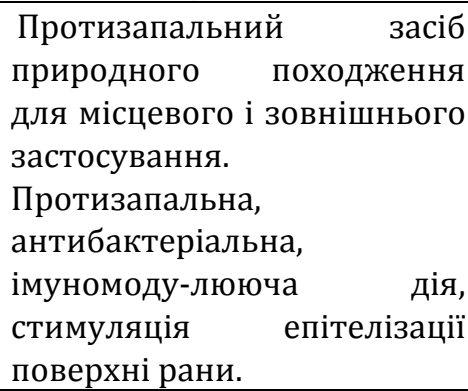 \\
\hline $\begin{array}{l}\text { Грязь } \\
\text { Мертвого } \\
\text { моря } \\
\text { натуральна } \\
\text { чорна }\end{array}$ & $\begin{array}{c}\text { Пластма- } \\
\text { совий } \\
\text { контейнер } \\
\text { по 0,3 кг }\end{array}$ & 195 & $\begin{array}{c}\text { Care \& } \\
\text { Beauty Line } \\
\text { (Ізраїль) }\end{array}$ & $\begin{array}{l}\text { Мінеральні } \\
\text { компоненти } \\
\text { лікувальної грязі } \\
\text { Мерт-вого моря }\end{array}$ & $\begin{array}{l}\text { Біогенний стимулятор. } \\
\text { Високоефективний за-сіб, } \\
\text { збагачений мінеральними } \\
\text { та органічними речовинами } \\
\text { широкого спектру дії. }\end{array}$ \\
\hline $\begin{array}{l}\text { Гумізоль } \\
\text { (Humisol }^{\circledR} \text { ) }\end{array}$ & $\begin{array}{c}\text { Розчин } \\
\text { для } \\
\text { ін'єкцій в } \\
\text { ампулах } \\
\text { по } 1 \text { і } 2 \text { мл } \\
\text { №10 } \\
\text { в упаковці }\end{array}$ & 592 & $\begin{array}{c}\text { Таллін- } \\
\text { нський } \\
\text { фармацевт } \\
\text { ичний } \\
\text { завод } \\
\text { (Естонія) }\end{array}$ & $\begin{array}{l}\text { 0,01\% розчин } \\
\text { фракцій } \\
\text { гумінових кислот } \\
\text { хаап-салуської } \\
\text { морської ліку- } \\
\text { вальної грязі в } \\
\text { ізотоніч-ному p- } \\
\text { ні NaCl (Бал- } \\
\text { тійське море) }\end{array}$ & 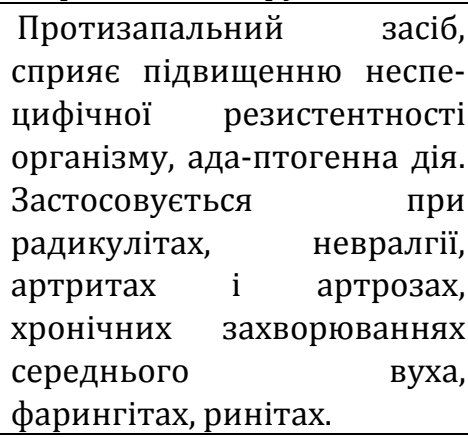 \\
\hline $\begin{array}{l}\text { Пелоїдин } \\
\text { (Peloidinum) }\end{array}$ & $\begin{array}{c}\text { Флакони } \\
\text { по } 500 \text { мл }\end{array}$ & 592,68 & $\begin{array}{c}\text { ГУП } \\
\text { Фармация, } \\
\text { м. } \\
\text { Єкатеринб } \\
\text { ург (Росія) }\end{array}$ & $\begin{array}{l}\text { Водний екстракт } \\
3 \\
\text { лікувальної грязі }\end{array}$ & $\begin{array}{l}\text { Високоефективний засіб, } \\
\text { збагачений мінераль-ними } \\
\text { та органічними речовинами } \\
\text { широкого спектру дії. } \\
\text { Застосовують } \\
\text { змочування серветок при } \\
\text { обробці гнійних ран. }\end{array}$ \\
\hline $\begin{array}{l}\text { Торфот } \\
\text { (Torfotum) }\end{array}$ & $\begin{array}{c}\text { Розчин } \\
\text { для } \\
\text { ін'єкцій в } \\
\text { амп. по } 1 \\
\text { мл №10 } \\
\text { у пачках }\end{array}$ & 300 & $\begin{array}{c}\text { Торрент } \\
\text { Фармасьют } \\
\text { ікалс } \\
\text { (Індія) }\end{array}$ & $\begin{array}{l}\text { Водний } \\
\text { торфу }\end{array}$ & $\begin{array}{l}\text { Загальнотонізуючий засіб } \\
\text { та адаптоген при артриті, } \\
\text { радикуліті, } \\
\text { блефариті, ко-н'юнктивіті, } \\
\text { кератиті, змутнення скло- } \\
\text { видного тіла. Ефективний } \\
\text { при недокрів'ї, отруєннях, } \\
\text { для регенерації шкіри. }\end{array}$ \\
\hline
\end{tabular}

\footnotetext{
* - вартість препарату перерахована у співвідношенні 1 руб =0,385 грн
} 
Таблиця 4.

Порівняльна характеристика вартості нативної грязі різних фірм-виробників

\begin{tabular}{|c|c|c|c|c|}
\hline $\begin{array}{c}\text { Найменування } \\
\text { препарату }\end{array}$ & Фірма-виробник & $\begin{array}{c}\text { Форма } \\
\text { випуску }\end{array}$ & $\begin{array}{c}\text { Ціна, } \\
\text { грн }\end{array}$ & $\begin{array}{c}\text { Вартість за } \\
1 \text { кг } \\
\end{array}$ \\
\hline Грязь «Сивашская» & $\begin{array}{c}\text { Sivash-Farm } \\
\text { (Україна, м. Запоріжжя) }\end{array}$ & Мішок по 20 кг & 1000,00 & 50,00 \\
\hline $\begin{array}{l}\text { Грязь тамбуканська } \\
\text { LIMINERA }\end{array}$ & $\begin{array}{c}\text { Кавминкурортресурсы } \\
\text { (Росія) }\end{array}$ & $\begin{array}{c}\text { Пластмасовий } \\
\text { контейнер } \\
\text { по 0,9 кг }\end{array}$ & 109,73 & 121,92 \\
\hline Грязь лікувальна & $\begin{array}{c}\text { CoolHealth } \\
\text { (м. Дніпро, Україна) }\end{array}$ & $\begin{array}{c}\text { Паста по } 500 \text { мл } \\
\text { у тубі }\end{array}$ & 85,00 & 170,00 \\
\hline $\begin{array}{lr}\text { Грязь } & \text { мулова } \\
\text { сульфідна лікувальна }\end{array}$ & $\begin{array}{c}\text { ГУНПП РК «Крымская } \\
\text { ГГРЭС» } \\
\text { (АР Крим) } \\
\end{array}$ & $\begin{array}{c}\text { Пластмасовий } \\
\text { контейнер } \\
\text { по 0,7 кг } \\
\end{array}$ & 123,00 & 175,71 \\
\hline $\begin{array}{l}\text { Грязь Мертвого моря } \\
\text { натуральна }\end{array}$ & $\begin{array}{l}\text { Care\&Beauty Line } \\
\text { (Ізраїль) }\end{array}$ & $\begin{array}{c}\text { Пластмасовий } \\
\text { контейнер } \\
\text { по 0,5 кг } \\
\end{array}$ & 140,00 & 280,00 \\
\hline $\begin{array}{l}\text { Грязь лікувальна } \\
\text { консервована }\end{array}$ & $\begin{array}{c}\text { Lac Sante } \\
\text { (Україна, м. Одеса) }\end{array}$ & $\begin{array}{c}\text { Пластмасовий } \\
\text { контейнер } \\
\text { по 0,330 кг } \\
\end{array}$ & 100,00 & 303,03 \\
\hline $\begin{array}{l}\text { Грязь мінеральна } \\
\text { «Куяльницький» }\end{array}$ & $\begin{array}{c}\text { Lac Sante } \\
\text { (Данія-Україна) }\end{array}$ & $\begin{array}{c}\text { Пластмасовий } \\
\text { контейнер } \\
\text { по 0,330 кг } \\
\end{array}$ & 108,00 & 360,00 \\
\hline $\begin{array}{l}\text { Грязь Мертвого моря } \\
\text { натуральна }\end{array}$ & $\begin{array}{c}\text { Dr. Sea } \\
\text { (Ізраїль) }\end{array}$ & $\begin{array}{c}\text { Пластмасовий } \\
\text { контейнер } \\
\text { по 0,6 кг } \\
\end{array}$ & 264,00 & 440,00 \\
\hline $\begin{array}{l}\text { Грязь Мертвого моря } \\
\text { без добавок }\end{array}$ & $\begin{array}{l}\text { SEA of SPA } \\
\text { (Ізраїль) }\end{array}$ & $\begin{array}{c}\text { Пластмасовий } \\
\text { контейнер } \\
\text { по 0,6 кг } \\
\end{array}$ & 320,00 & 533,33 \\
\hline $\begin{array}{l}\text { Грязь Мертвого моря } \\
\text { натуральна }\end{array}$ & $\begin{array}{c}\text { Ahava Natural Dead } \\
\text { (Ізраїль) }\end{array}$ & $\begin{array}{c}\text { Пластмасовий } \\
\text { контейнер } \\
\text { по 0,6 кг }\end{array}$ & 390,00 & 650,00 \\
\hline $\begin{array}{l}\text { Грязь Мертвого моря } \\
\text { натуральна чорна }\end{array}$ & $\begin{array}{l}\text { Care\&Beauty Line } \\
\text { (Ізраїль) }\end{array}$ & $\begin{array}{c}\text { Пластмасовий } \\
\text { контейнер } \\
\text { по 0,3 кг }\end{array}$ & 195,00 & 650,00 \\
\hline Грязь лікувальна & $\begin{array}{l}\text { Byothea } \\
\text { (Італія) }\end{array}$ & $\begin{array}{c}\text { Пластмасовий } \\
\text { контейнер } \\
\text { по } 1 \text { кг } \\
\end{array}$ & 835,00 & 835,0 \\
\hline Грязь лікувальна & Histomer (Італія) & Саше по 0,1 кг & $115,50^{*}$ & 1155,0 \\
\hline
\end{tabular}

* - вартість препарату перерахована у співвідношенні 1 руб = 0,385 грн

Відмічається постійне зростання частки ПП не лише на вітчизняному, але й загальносвітовому на фармацевтичному ринку, що обумовлено їх перевагами та високими лікувально-оздоровчими характеристиками. Ця динаміка свідчить, що за бальнеогрязьовими препаратами велике майбутнє, вони затребувані, конкурентноспроможні та займають значну нішу на вітчизняному фармацевтичному ринку. Разом з цим, за даними Фізор Н.С. i Тарасової К.В. (2012), на сьогодні в Україні виробляється лише $5 \%$ асортименту вітчизняних ПП від загального асортименту існуючих на фармацевтичному ринку. Цілком обгрунтованою $€ \quad$ перспективність використання пелоїдів для створення нових бальнеогрязьових ЛЗ із широкою терапевтичною дією [22]. Високоефективним $€$ проведення комплексного лікування:

1. поєднання пелоїдотерапії (застосування нативної грязі або ПП) із лікувальною фізкультурою загальновизнано ефективним засобом при доліковуванні наслідків поранень, фізичних і психологічних травм воєнного часу [8];

2. призначення ЛГ і мінеральних ванн (за методикою чергування); часовий проміжок між процедурами має становити понад 1-2 год, адже сольові компоненти МВ, осідаючи тонким шаром на поверхні тіла під час 
процедури і після неї, викликають подразнення рецепторів шкіри $[1,5]$.

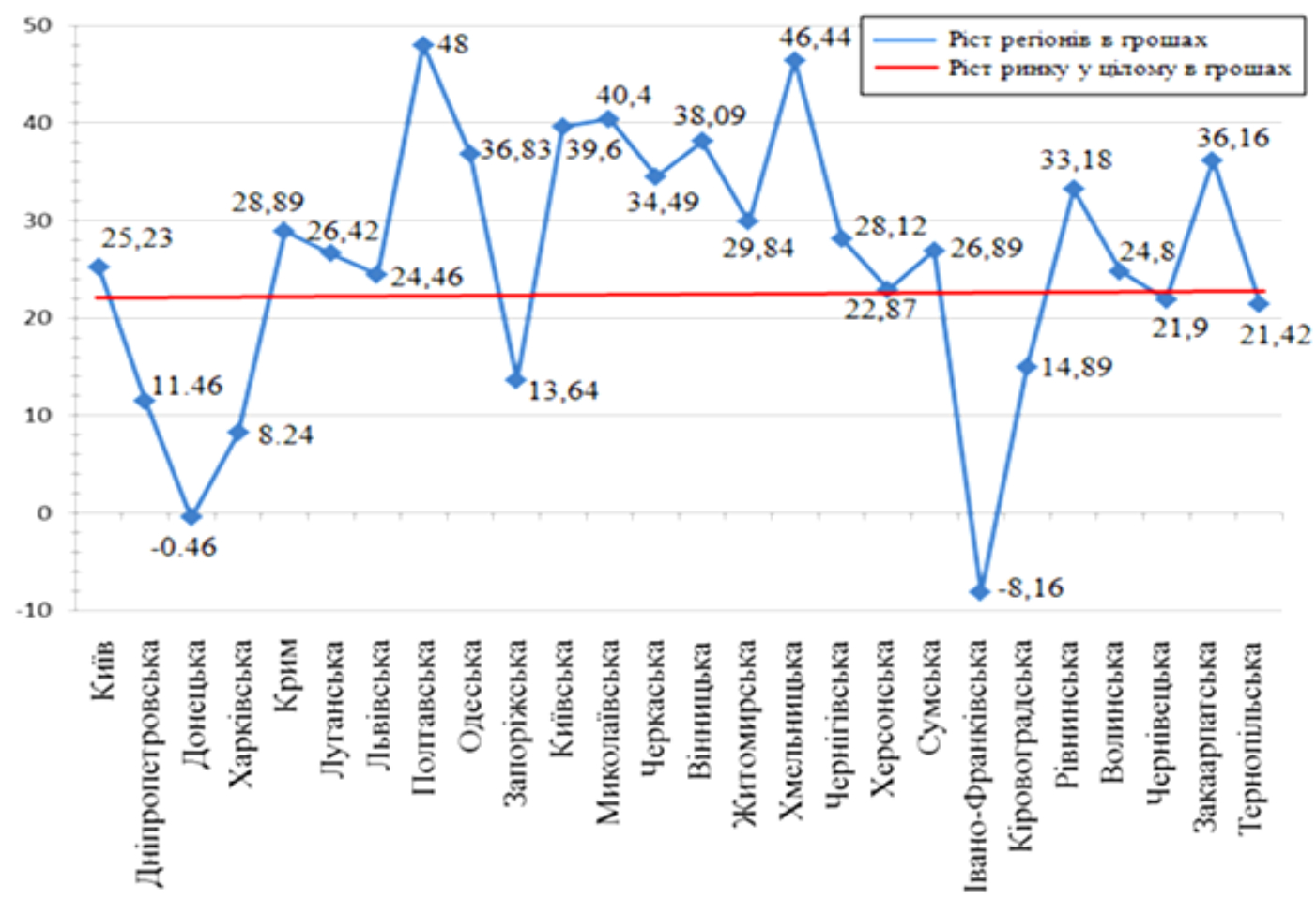

Рисунок 1. Тенденція витрат і зростання грошової маси в загальній кількості закупок пелоїдопрепаратів за регіонами України (станом на 01.01.2019р.).

На підставі вивчення досвіду лікування грязями, зокрема на курорті «Кирилівка» (Запорізька обл.), фахівці

\section{Висновки}

1. Зацікавленість до рекреаційних можливостей навколишнього середовища триває упродовж не одного тисячоліття. Прослідковано історико-хронологічні та нормативно-правові аспекти застосування ЛГ, які більшістю фахівців вважаються найпотужнішим лікувально-оздоровчим фактором. Власне 3 його відкриттям i використанням історично розпочався розвиток курортів, а згодом і використання рекреаційних ресурсів окремих регіонів.

2. Україну віднесено до провідних мінерально-сировинних країн Європи 3 тотожними природними умовами та запасом лікувальних ресурсів (5\% мінеральносировинного потенціалу світу). Узагальнені характеристики українських пелоїдів. Акцент зроблено на найбільш ресурсозбалансованих південно-східних регіонах - Дніпропетровському та Запорізькому.

3. Порівняльна оцінка ресурсів ЛГ цих регіонів виявила схожість типу мінералізації (сульфідно-мулові); дозволила свівставити відмічають: 98 \% після повного курсу фанготерапії виписуються зі значним поліпшенням здоров'я [8]. потужність родовищ і означити більшу активність пелоїдів Запоріжжя (причому в загальноукраїнських масштабах).

4. Прослідковано взаємозв'язок між кількісно-якісними показниками найпотужніших бальнеогрязьових джерел, розташованих на території кожної 3 двох областей, i напрямками проведення санаторно-курортного лікування. Вичленено водогрязелікарні та інші заклади, що спеціалізуються на обслуговуванні осіб 3 інвалідністю, учасників ООС. Означено, що на особливий період вони повинні перетворитися у військові госпіталі та використовуватися за призначенням.

5. Наголошено, що унікальний склад пелоїдів обумовлює високоефективний вплив як на місцевий запальний процес, так й на всі основні органи та системи (насамперед, опорно-руховий апарат, ССС, систему дихання, обмін речовин тощо). Грязелікування дозволяє суттєво прискорити загоєння ран різної етіології; скоротити період реабілітації 
(після перенесених бойової травми, хірургічних втручань, тяжких тривалих захворювань) i повернути військовослужбовця до строю. Узагальнені сучасні підходи до проведення пелоїдотехніки, вичленено найбільш затребувані процедури (грязьові ванни та аплікації).

6. Максимально ефективне проведення курсів пелоїдолікування в санаторнокурортних закладах, на території/поблизу яких $\epsilon$ власні родовища ЛГ (грязьові озера в Бердянську). За відсутністю такої можливості, суттєво полегшити стан хворого/ пораненого/ травмованого та прискорити одужання дозволяє застосування ПП, які за фізико-хімічними властивостями майже тотожні грязьовому розчину нативної грязі.

7. Проведено маркетингове дослідження бальнеогрязьових препаратів як сегментів фармацевтичного ринку. Відмічена його насиченість за країнами-виробниками, асортиментом, можливими ЛФ. Загалом авторами уніфіковано 55 ПП від різних виробників. Означено, що найбільшим попитом користуються ЛГ або ЛГ консервовані виробництва Sivash-Farm (м. Запоріжжя) та CoolHealth (м. Дніпро). В ході проведення цінової сегментації визначено найбільш економічну позицію - «Грязь Сивашская» (50 грн/кг) і середню вартість на

\section{Література}

1. Автушенко І.Б. Санаторно - курортне лікування як важлива складова медичного забезпечення військовослужбовців 3C України. 2013. URL: https://www.irbis-nbuv.gov.ua (дата звернення 26.07 2019).

2. Білик I.I., Тамбовцев Г.В., Непша О.В. Природні рекреаційні ресурси північного узбережжя Азовського моря в межах Запорізької області. Актуальные научные исследования в современном мире (ISCIENCE.IN.UA). Переяслав-Хмельницкий, 2019. Выпуск 3 (47). Ч. 2. С. 89-94. ISSN 2524-0986. Index Copernicus

3. Бриндіков Ю.Л. Методологічні принципи реабілітації військовослужбовців-учасників бойових дій. Педагогічні науки : збірник наукових праць. Херсонський державний університет. Херсон, 2017. Вип. LXXVII (77). Том 2. C. 149-153. Index Copernicus

4. Гайда I.М. Медико-соціальне обгрунтування удосконалення системи медичної реабілітації військовослужбовців на регіональному рівні : дис... канд. мед. наук : 14.02.03. УВМА МО України. Ужгородський національний університет МOH нативну грязь на світовому фармацевтичному ринку $(440,31$ грн/кг), що свідчить про їх економічну доступність. Відмічено постійне зростання частки ПП не лише на вітчизняному, але й загальносвітовому фармацевтичному ринку, що обумовлено перевагами та високими лікувальнооздоровчими характеристиками.

8. Доведено, що Дніпропетровська та Запорізька області мають значний природний рекреаційно-ресурсний потенціал, який на сьогодні реалізовано не в повній мірі. Його застосування для потреб ЗС України $\epsilon$ раціональним і доцільним, адже наявність військового напрямку лікувальнопрофілактичної роботи не викликає сумнівів.

9. Представлений матеріал можливо розглядати як платформу для оптимізації практичного застосування ПРРП країни у якості замісної терапії протягом мирного періоду та після завершення бойових дій для особового складу військових частин, що дислокуються на певних територіях. Спектр відповідних лікувально-профілактичних послуг постійно розширюється. Це накладає відповідальність на керівників структурних підрозділів щодо обов'язкового періодичного проходження курсів удосконалення військово-медичних працівників в закладах післядипломної освіти.

України. Київ, 2018. 278 с. Державний обліковий №0419U000272

5. Грязелечение: лечебные грязи, грязевые курорты (фанготерапия, пелоидотерапия). URL: http://sankurtur.ru/ methods/371 (дата звернення 15.08.2019).

6. Екологічні паспорти регіонів (25 областей України), 2018-2019 pp. URL: https://menr.gov.ua/content/ekologichni-pasportiregioniv.html (дата звернення 15.08.

7. Карагулов Х.Г. Создание и методология лекарственных и космецевтических средств, содержащих тамбуканские пелоиды, на основе современных ресурсосберегающих технологий: автореф. дис... д-ра фармац. наук : 15.00.01. Пятигорск, 2017. 320 с. URL: www.dissercat.com > content

8. Кравець О.М., Рябєв А.А. 0 Конспект лекцій з дисципліни «Курортологія». Харківський національний університет міського господарства ім. О.М. Бекетова. Харків: ХНУМГ ім. О.М. Бекетова, 2016. 102 c. URL: http://eprints.kname.edu.ua/ 43523 
9. Крамаренко М.О. Наукові засади архітектурнопланувальної організації курортних готелів: дис... канд. архітектури: 18.00.02. Одеська державна академія будівництва і архітектури. Київ, 2018. 217 с. URL: http://mx.ogasa.org.ua/handle/ 123456789/7303

10. Кучмістова О.Ф. Структуризація хронологічного та подієвого підходу до пелоїдолікування у дзеркалі історії. Матеріали VI Міжнародної науково-практичної INTERNETконференції «Соціальна фармація: стан, проблеми та перспективи» (м. Харків, квітень 2020 р.). Харків, HФаУ, 2020. C. 46-52. URL: https://sci-conf. com.ua

11. Кучмістова О.Ф., Шматенко О.П., Кучмістов В.О. Моніторинг фіторесурсів Південно-Східних регіонів України для потреб військово-медичної служби. Topical issues of the develpoment of modern science. Abstracts of the $9^{\text {th }}$ Intern. scientific and practical conf. Publishing House «ACCENT». Sofia, Bulgaria. 2020. P. 484493. URL: https://sci-conf. com.ua

12. Мурадов С.В. Микробиологические свойства и биомедицинское тестирование пелоидных препаратов из активированной лечебной грязи. Вестник новых медицинских технологий. 2014. Т. 20. №4. C. 38-41. URL: http://www. vmnmt.ru

13. Мурадов С.В. Экологические и микробиологические особенности формирования и состояния месторождений лечебных грязей: дис... дра биол. наук: 03.02.08, научно-исследоват. геотехнолог. центр Дальневосточного отделения PAM. Томск, 2014. 237 c. URL: http://www.tsu.ru

14. Парфіненко А.Ю., Волкова I.I., Щербина B.I. Проблеми та перспективи розвитку лікувальнооздоровчого туризму в Україні (У порівнянні 3 країнами Центральної Європи). Вісник Харківського національного університету ім. В.Н. Каразіна. 2018. С. 130-135.

DOI: https://doi.org/10.26565/2310-9513-2018-7-19

15. Про затвердження Загальнодержавної програми розвитку мінерально-сировинної бази України на період до 2030 року: Закон України від 21.04.2011 р. №3268-VI. Відомості Верховної Ради України. 2011. № 44. Ст. 457. (розділ III). URL: http://zakon4.rada.gov.ua

\section{References}

1. Avtushenko, I.B. (2013). Sanatorno - kurortne likuvannya yak vazhlyva skladova medychnogo zabezpechennya viyskovosluzhbovtsiv ZS Ukrainy [Sanatorium-resort treatment as an important component of medical support of servicemen of the Armed Forces of Ukraine]. Retrieved from https://www.irbis-nbuv.gov.ua [in Ukrainian].

2. Bilyk, I.I., Tambovtsev, H.V. \& Nepsha, O.V. (2019) Pryrodni rekreatsiyni resursy pivnichnogo uzberezhzhya Azovskogo morya v mezhakh Zaporizkoy oblasti [Natural recreational resources of the northern coast of the Sea of Azov within the Zaporozhye region]. Aktualnye nauchnye issledovaniya $v$ sovremennom mire (ISCIENCE.IN.UA). Pereyaslav-Khmelnitskiy. 3 (47), 2, 89-94. [in Ukrainian].
16. Радиш Я.Ф., Соколова О.М. Медична реабілітація українських військовослужбовців, що постраждали в результаті бойових дій (до проблеми державного регулювання системи санаторно-курортного забезпечення військовослужбовців Збройних Сил України). Інвестиції: практика та досвід. 2014. № 24. C. 152-155. URL: http://www.irbis-nbuv.gov.ua

17. Радиш Я.Ф., Мегедь В.П., Соколова О.М., Чорний І.П. Механізми державного регулювання санаторнокурортного лікування та медичної реабілітації військовослужбовців в Україні: генезис $і$ тенденції розвитку. URL: http://archive. nbuv.gov.ua/portal/socgum (дата звернення 02.08.2019).

18. Соколова О.М. Санаторно-курортне лікування важлива складова реабілітації українських військовослужбовців. Інвестиції: практика та досвід. 2014. № 23. C. 149-152. URL: http://www.irbisnbuv.gov.ua

19. Соколова О.М., Васюк Н.О., Радиш Я.Ф. Реабілітація військовослужбовців: термінологія, класифікація, принципи та особливості (до проблеми державного регулювання реабілітації особового складу Збройних Сил України). Інвестиції: практика ma досвід, 2015. №23. C. 148-155. URL: http://www.irbis-nbuv.gov.ua

20. Тарасенко В.О., Кучмістова О.Ф., Соломенний A.М., Підлісний О.В. Структуризація особливостей та наслідків бойової травми у військовослужбовців. Військова медищина України. т. 19, № 4. 2019. С. 111117. URL: http://uvma.mil. gov.ua

21. Тарасов В.В. Флора Дніпропетровської та Запорізької областей. Дніпропетровськ : Вид-во ДНУ; Лipa, 2012. 296 с. ISBN 978-966-383-416-0

22. Фізор Н.С., Тарасова К.В. Вивчення цілющих властивостей вітчизняних лікувальних грязей i перспективи створення нових лікарських форм на їх основі. Одеський державний університет. Актуальні питання фармацевтичної $i$ медичної науки та практики. 2012. №3 (10). С. 23-25. URL: http://nbuv.gov.ua/ UJRN/ apfimntp_2012 38

3. Bryndikov Yu.L. (2017). Metodologichni pryntsypy reabilitatsii viyskovosluzhbovtsiv-uchastnykiv boyovykh diy [Rehabilitation's methodological principles for combatant servicemen]. Pedagogichni nauky : zbirnyk naukovykh prats. Khersonskyy derzhavnyy universytet. Kherson. LXXVII (77), 2, 149-153. [in Ukrainian].

4. Hayda, I.M. (2018). Mediko-sotsialne obgruntuvannya udoskonalennya systemy medychnoyi reabilitatsii viyskovosluzhbovtsiv na regionalnomu rivni [Medico-social substantiation of improvement of medical rehabilitation system for servicemen at the regional level]. [Dys. kand. med. nauk]. UVMA MO Ukrayiny. Uzhgorodskiy natsionalnyy universitet MON Ukrayiny. Kyiv. [in Ukrainian]. 
5. Gryazelechenie : lechebnye gryazi, gryazevye kurorty (fangoterapiya, peloidoterapiya) [Mud treatment : therapeutic mud, mud spas (phangotherapy, peloidotherapy)]. Retrieved from http://sankurtur.ru/ methods/371 [in Russian].

6. Ecologikal passports of regions (25 regions of Ukraine), $2018 \quad$ - $2019 \quad$ [Regions ecological passports (25 regions of Ukraine), 2018 -

2019.]. Retrieved from https://menr. gov.ua/content/ekologichni-pasporti-regioniv.html (дата звернення 15.08.2019). [in Ukrainian].

7. Karagulov, Kh.G. (2017). Sozdanie i metodologiya lekarstvennykh $i$ kosmetsevticheskikh sredstv, soderzhashchikh tambukanskie peloyidy, na osnove sovremennykh resursosberegayushchikh tekhnologiy. [Creation and methodology of medicines and cosmeceuticals containing Tambukan peloids based on modern resource-saving technologies]. [Автореферат дис. д-ра фармац. наук]. Pyatigorskiy medikofarmacevticheskiy institut, Пятигорск, 2017. [in Russian].

8. Kravets, O.M., Ryabev, A.A. (2016). Konspekt lektsiy $\mathrm{z}$ dystsypliny «Kurortologiya» [Summary of lectures on the «Balneology» subject]. Kharkivskiy natsionslnyy universitet miskogo gospodarstva im. O.M. Beketova. Kharkiv: KhGUMG im. O.M. Beketova. 102 p. [in Ukrainian].

9. Kramarenko, M.O. (2018). Наукові засади архітектурно-планувальної організації курортних готелів [Scientific principles of resort hotels architectural and planning organization]. [Дис. канд. архітектури], Одеська державна академія будівництва і архітектури, Київ. [in Ukrainian].

10. Kuchmistova, O.F. (2020). Strukturizatsiya khronologichnogo ta podievogo pidkhodu do peloyidolikuvannya $\mathrm{u}$ dzerkali istorii [Structuring the chronological and event approach to peloid treatment in the history mirror]. Materialy VI Mizhnarodnoyi naukovopraktychnoyi INTERNET-konferencii «Sotsialna farmatsiya: stan, problemy ta perspektyvy» (Kharkiv, 2020). Kharkiv, NFAU. 46-52. [in Ukrainian].

11. Kuchmistova ,O.F., Shmatenko, O.P. \& Kuchmistov, V.O. (2020). Monitoring fitoresursov Pivdenno-Skhidnykh regioniv Ukrainy dlya potreb viyskovo-medychnoyi sluzhby [Monitoring of South-Eastern regions of Ukraine phytoresources for the needs of the military medical service]. Topical issues of the develpoment of modern science. Abstracts of the $9^{\text {th }}$ Intern. scientific and practical conf. Publishing House "ACCENT». Sofia, Bulgaria, 2020. 484-493. [in Ukrainian].

12. Muradov, S.V. (2014). Mikribiologicheskie svoystva i boiomeditsynskoe testirovanie peloyidnykh preparatov iz aktivirovannoy lechebnoy gryazi [Microbiological properties and biomedical testing of peloid preparations from activated therapeutic mud]. Vestnik novykh meditsynskikh tekhnologiy. 20 (4), 38-41 [in Russian].

13. Muradov, S.V. (2014). Ekologicheskie $i$ mikrobiologicheskie osobennosti formirovaniya $i$ sostoyaniya mestorozhdeniy lechebnykh gryazey [Ecological and microbiological features of the formation and condition of therapeutic mud deposits]. [Dis. d-ra biol. nauk]. Nauchno-issledovat. geotekhnolog. tsentr Dalnevostochnogo otdeleniya RAM, Tomsk [in Russian].

14. Parfinenko, A.Yu., Volkova, I.I. \& Shcherbina, V.I. (2018). Problemy ta perspektyvy rozvytku likuvalnoozdorovchogo turyzmu $\mathrm{v}$ Ukraini ( $\mathrm{u}$ porivnanni $\mathrm{z}$ krayinamy Tsentralnoyi Yevropy) [Problems and prospects of medical and health tourism development in Ukraine (in comparison with the countries of Central Europe)]. Visnyk Kharkivskogo natsionalnogo universitetu im. V.M. Karamzina. 130-135 [in Ukrainian]. Retrieved from https://doi.org/ 10.26565/2310-9513$\underline{\text { 2018-7-19 }}$

15. Pro zatverdzhennia Zahalnoderzhavnoi prohramy rozvytku mineralno-syrovynnoi bazy Ukrainy na period do 2030 roku [On approval of the National Program for Development of the Mineral Resources Base of Ukraine for the period up to 2030] (2011): Zakon Ukrainy 21.04.2011 № 3268-VI. Vidomosti Verkhovnoi Rady Ukrainy, 44, 457: III [in Ukrainian].

16. Radysh, Ja.F., Sokolova, O.M. (2014). Medychna reabilitatsiya ukrayinskikh viyskovosluzhbovtsiv, shcho postrazhdaly $\mathrm{v}$ rezultati boyovykh diy (do problemy derzhavnogo regulyuvannya systemy sanatornokurortnogo zabezpechennya viyskovosluzhbovtsiv Zbroynykh Syl Ukrayiny)[Medical rehabilitation of the ukrainian servicemen having suffered as a result of the battles (as regard to the problem of the government control of the system of the sanatorium and health resort provision of the servicemen of the ukrainian armed forces]. Investytsiyi: praktyka ta dosvid, 24, 152-155 [in Ukrainian].

17. Radysh, Ja.F., Meged V.P., Sokolova O.M. \& Chornyy, I.P. (2019) Mekhanizmy derzhavnogo regulyuvannya sanatorno-kurortnogo likuvannya ta medychnoyi reabilitatsii viyskovosluzhbovtsiv $\mathrm{v}$ Ukrayini: geneziz $\mathrm{i}$ tendentsii rozvytku [Mechanisms of state regulation of sanatorium treatment and medical rehabilitation for servicemen in Ukraine: genesis and development trends]. Retrieved from http://archive.nbuv.gov.ua/portal/ socgum

18. Sokolova, O.M. (2014). Sanatorno - kurortne likuvannya - vazhlyva skladova reabilitatsii ukrayinskikh viyskovosluzhbovtsiv [Sanatorium treatment is an important component of the rehabilitation of Ukrainian servicemen]. Investytsii: praktika ta dosvid. 23, 149-152 [in Ukrainian].

19. Sokolova, O.M., Vasyuk N.O. \& Radysh Ya.F. (2015). Reabilitatsiya viyskovosluzhbovtsiv: terminologiya, klasyfikatsiya, pryntsypy ta osoblyvosti (do problemy derzhavnogo regulyuvannya reabilitatsii osobovogo skladu Zbroynykh Syl Ukrayiny) [Rehabilitation of servicemen: terminology, classification, principles and features

(considering problems of state regulation of rehabilitation of Armed Forces of Ukraine personnel). Investytsii: praktika ta dosvid. 23, 148-155 [in Ukrainian]. 
20. Tarasenko, V.O., Kuchmistova, O.F., Solomennyy, A.M. \& Pidlisnyy O.V. (2019). Strukturyzatsiya osoblyvostey ta naslidkiv boyovoyi travmy $\mathrm{u}$ viyskovosluzhbovtsiv

[Structuring the features and consequences of servicemen combat traumas]. Viyskova medytsyna Ukrayiny. 19 (4), 111-117 [in Ukrainian].

21. Tarasov, V.V. (2012). Flora Dnipropetrovskoyi ta Zaporizkoyi oblastey [Dnipropetrovsk and Zaporizhia regions flora]. Dnipropetrovsk : Vyd-vo DNU; Lira. 296 p. [in Ukrainian].
22. Fizor, N.S., Tarasova, K.V. (2012). Vyvchennya tsilyushchykh vlastyvostey vitchyznyanukh likuvalnykh gryazey i perspektyvy stvorennya novykh likarskykh form na yikh osnovi [Domestic therapeutic muds healing properties study and prospects for new medicine creation based on them. Odeskiy derzhavnyy universitet. Aktualni pytannya farmatsevtychnoyi i medychmoyi nauky ta praktyky. 3 (10), 23-25 [in Ukrainian].

\title{
ПУТИ ОПТИМИЗАЦИИ ФАНГОКОРРЕКЦИИ СОСТОЯНИЯ ЗДОРОВЬЯ ВОЕННОСЛУЖАЩИХ: РЕКОМЕНДАЦИИ ВРАЧУ-РЕАБИЛИТОЛОГУ
}

\author{
А.П. Шматенко ${ }^{1}$, Е.Ф. Кучмистова ${ }^{1}$, И.В. Бушуева ${ }^{2}$, \\ В.А. Тарасенко ${ }^{1}$, В.А. Кучмистов ${ }^{1}$, А.М. Кричковская ${ }^{3}$ \\ 1 Украинская военно-медицинская академия (2. Киев) \\ 2 Запорожский государствнный медицинский университет (2. Запорожье) \\ ${ }^{3}$ Национальный университет «Львовская политехника» (2. Львов)
}

Введение. Успешное решение задач, возложенных на медицинскую службу требует высокого уровня обеспечения личного состава отечественных Вооруженных Сил максимально широким спектром лечебно-профилактических средств, в т.ч. природного происхождения. Украина занимает лидирующие позищии среди европейских стран по уровню обеспеченности ценными природными лечебными ресурсами. Среди наиболее ресурсообеспеченных особо выделяются Днепропетровская и Запорожская области, що и обусловило обьект исследования. Как показал скрининг-анализ, до сегодняшнего дня остаются полностью не изученными особенности формирования ресурсного потенциала этих регионов, не обобщались консолидированные возможности проведения лечебно-реабилитационной работы средствами природного происхождения среди военнослужащих на соответствующих курортных и внекурортных территориях.

Цель - оптимизация использования рекреационных возможностей южно-восточных регионов Украины в местах возможной дислокации военнослужащих.

Материалы и методы. В ходе работы использовались общенаучные и системно-обзорные методы информационного поиска: скрининг-анализ, систематизация и интерпретация ее результатов, маркетинговые исследования.

Результаты исследования. Впервые проведена сравнительная количественно-качественная оценка наиболее богатых бальнеогрязевых источников как составляющей природного рекреационноресурсного потенциала Днепропетровской и Запорожской областей. Показана взаимосвязь между выявленными ресурсами пелоидов и направлениями стационарного лечения в реабилитационном отделении санаторно-курортных заведений на территории этих регионов. Фрагментарно представлены результаты маркетингового исследования бальнеогрязевых препаратов как сегментов фармацевтического рынка. Отмечена его насыщенность по странам-производителям, ассортименту, возможным лекарственным формам. Акцентированы четкие преимущества пелоидопрепаратов по сравнению с растворами нативной грязи, свойства которых практически схожи между собой. Вичленены наиболее интересные позиции для возможного расширения спектра проведения восстановительного лечения военнослужащих, особенно на местах соответствующей дислокации, что вполне логично и уместно.

Выводы. Сравнительная оценка ресурсов двух регионов выявила сходство типа минерализации грязей (сульфидно-муловые) и соответствующего спектра оказания лечебно-реабилитационных услуг в условиях санаторно-курортных заведений на этих территориях. Вычленено водогрязелечебницы и другие заведения, которые специализируются на обслуживании участников ООС. Акцентировано внимание на том, что на протяжении особенного периода они обязаны выполнять функциональные задачи военных госпиталей и использоваться по назначению. Проанализованы многочисленные случаи успешной реабилитации последствий военных травм, ранений разной этиологии, переломов, хирургических вмешательств, тяжелых длительных заболеваний после прохождения курса нативных грязей или пелоидопрепаратов. Приведенные примеры не исчерпывают возможный лечебный потенциал пелоидов в качестве заместительной терапии, что определяет актуальность дальнейшей разработки новых лекарственных средств на их основе. Обобщены современные подходы к проведению пелоидотехники. Рационально продолжить исследования указанного направления, что расширит рамки реализации 
оздоровительно-рекреационного ресурса каждого региона України. Это позволит максимально сократить продолжительность подострого периода реабилитации и ускорить возвращение военнослужащего в строй. Изложенный материал доказывает, что грязелечение должно оставаться неотьемлимой составляющей реабилитационной программы для личного состава отечественных Вооруженных Сил, особенно в современных исторических условиях.

Ключевые слова: военнослужащие, лечебные грязи, пелоиды, пелоидопрепараты, реабилитация, Днепропетровская и Запорожская области.

\title{
APPROACHES FOR OPTIMISATION OF PELOTHERAPIA OF SERVICEMEN: RECOMMENDATIONS FOR PHYSIATRISTS
}

\author{
1O.P. Shmatenko, ${ }^{1}$ O.F. Kuchmistova, ${ }^{2}$ I.V. Bushueva, \\ ${ }^{1}$ V.A. Tarasenko, ${ }^{1}$ V.O. Kuchmistov, ${ }^{3}$ A.M. Krychkovska \\ 1 Ukrainian Military Medical Academy, Kyiv \\ 2 Zaporizhzhya State Medical University, Zaporizhzhya \\ ${ }^{3}$ Lviv Poliytechnic National University, Lviv
}

Introduction. A successful problem addressing, imposed on the medical service, requires a high-level supply of domestic military personnel with the widest possible range of preventive and curative measures, including of the natural origin. Ukraine sets the leading position among European countries for the level of valuable natural curative resources the richest considered to be Dnipropetrovsk and Zaporizhzhya regions, which defined the subject of research. According to screening analysis, the nature of the formation of natural resource potential in these regions remain unclear, the summary data of the robust possibilities of curative-rehabilitation of military personnel (by natural origin means) at resort therapy and out-of-resort territories is not structured.

The purpose: to extend possibilities to optimise the use of recreation potential of South-Eastern regions of Ukraine in places of possible deployments of military personnel.

Materials and methods. We used general scientific and systematic survey methods of information search, including screening analysis, categorisation and interpretation of search results and marketing researches.

Results. For the first time, we conducted a comparative quantitative and qualitative assessment of the highenergy balneo-mud sources as part of the recreation and natural resource potential of Dnipropetrovsk and Zaporizhzhya regions. We looked into interrelation or identified peloid resources with inpatient treatment possibilities at rehabilitation facilities of resorts on the territory of mentioned regions. On a piecemeal basis, we highlighted the results of the marketing research of balneo-mud therapeutics as segments of the pharmaceutical market. We scored down the fact of market saturation by countries of origin, variety and possible pharmaceutical form. We outlined obvious advantages of peloidal formulations in comparison to dilutions of native mud, properties of which are identical. We distilled the most interesting headings for possible expansion of military personnel rehabilitative treatment range, especially at dislocation points, which is understandable and appropriate.

Conclusions. Comparative assessment of the relevant resources in selected regions showed certain similarities between the types of mud mineralisation (sulfide silt) and the corresponding range of curative and rehabilitation services within health resorts located on these territories. We carved out balnearies and other health care facilities which specialise on servicing military personnel, participants of Joint Forces Operation (JFO). We pointed out that during the exceptional time such facilities must be transformed into military hospitals and be used as intended. Numerous cases of successful rehabilitation (post-use of native muds or peloids course) of the consequences of military injuries, wounds of various aetiology, fractures, surgical incisions, protracted severe diseases, were analysed from a cause-and-effect view. Listed example cases are not limiting the curative peloid potential as a supportive therapy, which in its turn defines the applicability to develop new pharmaceutical products on its basis. We consider it is reasonable to continue the research, which will allow extending deployment limits of therapeutic and recreational resource of each region in Ukraine. This will minimise the subacute rehabilitation period and allow servicemen to step back to the service. Presented information proves that fangotherapy must remain an essential part of the rehabilitation programme for military personnel, especially in modern momentous conditions.

Keywords: military personnel, therapeutic muds, peloids, peloid products, rehabilitation, Dnipropetrovsk region, Zaporizhzhia region.

Конфлікт інтересів: відсутній.

Conflicts of interest: authors have no conflict of interest to daclare. 


\section{Відомості про авторів:}

Шматенко О.П. Е,F доктор фармацевтичних наук, професор, полковник медичної служби, начальник кафедри військової фармації Української військово-медичної академії, м. Київ.

Кучмістова О.Ф. A,B,C,D,E,F кандидат біологічних наук, доцент, професор кафедри військової фармації Української військово-медичної академії, м. Київ.

Бушуєва I.B. C,D,F доктор фармацевтичних наук, професор, завідувач кафедрою управління і економіки фармації та технології ліків Запорізького державного медичного університету, м. Запоріжжя.

Тарасенко B.O. А,Е,F кандидат фармацевтичних наук, доцент, доцент кафедри військової фармації Української військово-медичної академії, м. Київ.

Кучмістов В.О. В,С,Е кандидат біологічних наук, доцент, доцент кафедри військової фармації Української військово-медичної академії, м. Київ.

Кричковська A.M. C,D,F кандидат фармацевтичних наук, доцент, доцент кафедри технології біологічно активних сполук, фармації та біотехнології Національного університету «Львівська політехніка», м. Львів.

$A$ - концепція та дизайн дослідження; B - збір даних; $C$ - аналіз та інтерпретація даних;

$D$ - написання статmi; $E$ - редагування статmі; F- остаточне затвердження статті.

\section{Сведения об авторах:}

Шматенко А.П., д-р фарм. наук, профессор, полковник медицинской службы начальник кафедры военной фармации Украинской военно-медицинской академии, г. Киев.

Кучмистова Е.Ф., канд. биол. наук, доцент, профессор кафедры военной фармации Украинской военно-медицинской академии, г. Киев.

Бушуева И.В., д-р фарм. наук, профессор, заведующая кафедрой управления, экономики фармации и технологии лекарств Запорожского государственного медицинского университета, г. Запорожье.

Тарасенко В.А., канд. фарм. наук, доцент, доцент кафедры военной фармации Украинской военномедицинской академии, г. Киев.

Кучмистов Виктор Алексеевич, кандидат биол. наук, доцент, доцент кафедры военной фармации Украинской военно-медицинской академии, г. Киев.

Кричковская А.М., канд. фарм. наук, доцент, доцент кафедры технологии биологически активных соединений, фармации и биотехнологии Национального университети «Львовская политехника», г. Львов.

\section{Information about authors:}

Shmatenko O.P. E,F Col. MS, DPSc, Professor, Head of the Department of Military Pharmacy, Ukrainian Military Medical Academy, Kyiv. E-mail: Olexandr shmatenko@ukr.net, https://orcid.org/0000-0002-6145$\underline{460 X}$

Kuchmistova O.F. A,B,C,D,E,F PhD, Associate Professor, Professor of the Department of Military Pharmacy, Ukrainian Military Medical Academy, Kyiv. E-mail: Helen.kuchmistoff@ukr.net, https://orcid.org/0000-0002$\underline{6028-2463}$

Bushueva I.V. C,D,F DPSc, Professor, Head of the Department of Management, Economics of Pharmacy and Drug Technology, Zaporizhzhya State Medical University, Zaporizhzhya, E-mail: valery999@ukr.net, https://orcid.org/0000-0002-5336-3900

Tarasenko V.O. A,E,F PhD, Associate Professor, senior lecturer of Military Pharmacy Department, Ukrainian Military Medical Academy, Kyiv, E-mail: vika tarasenko83@ukr.net, https://orcid.org/0000-0002-3614-6752

Kuchmistov V.O. B,C,E PhD, Associate Professor, Associate Professor of the Department of Military Pharmacy, Ukrainian Military Medical Academy, Kyiv, E-mail: victor.kuchmistov@gmail.com, https://orcid.org/0000-0001-9632-3100

Krychkovska A.M. C,D,F PhD, Associate Professor, Associate Professor of the Department of Technology of Biologically Active Compounds, Pharmacy and Biotechnology, National University «Lviv Poliytechnic», Lviv.

E-mail: aelitakrychkovska@gmail.com, https://orcid.org/0000-0002-0112-5003

$A$ - research concept and design; $B$ - collection and/or assembly of data; $C$ - data analysis and interpretation;

$D$ - writing the article; $E$ - critical revision of the article; $F$ - final approval of the article.

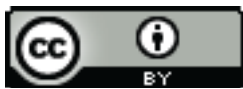

Адреса для листування: вул. Московська, 45/1, буд. 33, м. Київ 01015 